\title{
RDF pirolíziséből származó koksz és barnaszén elgázosításának vizsgálata laboratóriumi körülmények
} között

\section{Laboratory-scale gasification of brown coal and char from RDF pyrolysis}

\author{
E. SEBE ${ }^{1}$, G. NAGY², A.A. KÁLLAY3 \\ ${ }^{1}$ Miskolci Egyetem, Műszaki Anyagtudományi Kar, Energia- és Minőségügyi Intézet, sebe.emese@uni-miskolc.hu \\ 2Miskolci Egyetem, Műszaki Anyagtudományi Kar, Energia- és Minőségügyi Intézet, nagy.gabi@uni-miskolc.hu \\ ${ }^{3}$ Miskolci Egyetem, Műszaki Anyagtudományi Kar, Energia- és Minőségügyi Intézet, tuzaak@uni-miskolc.hu
}

\begin{abstract}
Absztrakt. A pirolizis ígéretes eljárás hulladékokból történő szintézisgáz elöállitásra. Azonban a technológia melléktermékeként visszamaradó szilárd anyag még jelentős mennyiségben tartalmazhat karbont, ezáltal akár további szintézisgáz előállítására is felhasználható. Kísérleteink során egy Zalaegerszegen múködô félüzemi méretû kísérleti pirolizáló berendezésből származó RDF pirolízise során visszamaradó koksz vízgőzzel történő elgázosítását vizsgáltuk $900{ }^{\circ} \mathrm{C}$-on, egy fix-ágyas laboratóriumi elgázosító rendszerben. Továbbá végeztünk kísérleteket felsőnyárádi barnaszénnel is. Jelen munka célja, hogy megvizsgáljuk hatékonyan alkalmazható-e a pirolízis koksz szintézisgáz előállítására, valamint, hogy feltárjuk és bemutassuk a vizsgált alapanyagok termokémiai lebontása során felfedezhető hasonlóságokat és különbségeket.
\end{abstract}

Abstract. The pyrolysis is a promising process for producing syngas from wastes. However, the by-product of the technology may contain large quantities of carbon, therefore it is suitable for further syngas production. In this paper we examined the steam gasification of brown coal from Felsônyárád and char from RDF pyrolysis derived from an experimental pilot plant operating in Zalaegerszeg. We performed our experiments in a laboratory-scale fix-bed reactor at $900{ }^{\circ} \mathrm{C}$. The aim of this work to examine the efficiency of syngas production from pyrolysis char, as well as to explore the similarities and differences of the thermal decomposition of the feedstock materials.

\section{Bevezetés}

A globális népességnövekedés okozta fokozódó energiaigény következtében egyre nagyobb ütemben használjuk fel bolygónk erőforrásait. A növekvő aggodalom és a környezetvédelmi szabályozások szigorodása a megújuló energiaforrások felhasználásának növekedését és a tisztább technológiák elterjedését eredményezte. A szén még napjainkban is az egyik legnagyobb mértékben felhasznált fosszilis energiahordozó [1]. A szénelgázosítást hosszú ideje alkalmazzák szintézisgáz előállítására, ugyanakkor egyre több kutatás foglalkozik más, költséghatékony alapanyagok (pl. pirolízis koksz) vizsgálatával a fenntartható fejlődés jegyében $[2,3]$. 
Korunk másik fő problémája a hulladékok mennyiségének rohamos növekedése. A megelőzés, újrahasználat és újrahasznosítás mellett kiemelten fontos az újrahasznosításra nem alkalmas hulladékok kezelésének kérdésköre. Ezen hulladékok energetikai hasznosításának egyik alternatívája a pirolízis, amely során az alapanyagból pirolízisgáz, pirolízis koksz és pirolízis olaj képződik. Mind az alapanyag, mind a technológia egyes paraméterei (hőmérséklet, felfütési sebesség, tartózkodási idő stb.) nagymértékben befolyásolják a keletkező termékek mennyiségét és minőségét [4]. Azonban egy olyan technológiánál is, melynek fő terméke a gáz, melléktermékként jelentős mennyiségű szilárd anyag maradhat vissza [5], melynek tárolásáról és kezeléséről gondoskodni kell. A szóban forgó anyag nem értéktelen, jelenleg főként energetikai célokra hasznosítják, vagy kis mértékű átalakításával hatékony adszorbens állítható elő belőle [6, 7]. Emellett elgázosítással akár szintézisgáz előállítására is felhasználható. A pirolízis koksz további hasznosítását nagymértékben meghatározza a pirolízis során alkalmazott alapanyag [8]. Szilárd települési hulladékok pirolízisekor az egyik legnagyobb nehézséget az alapanyag összetételének folyamatos változása jelenti, melynek következményeként a termékek is változó paraméterekkel rendelkeznek. Ugyanakkor a szilárd települési hulladékokból előállítható egy másodlagos tüzelőanyag, melyet a szaknyelvben RDF-nek (refuse derived fuel) neveznek. Ennek egyik előnye, hogy összetétele már kisebb skálán változik.

Korábbi kutatásainkhoz kapcsolódóan egy Zalaegerszegen létesített félüzemi kísérleti berendezésben RDF pirolízisekor keletkező koksz vízgőzzel történő elgázosításának lehetőségeit kívánjuk jelen munka keretein belül bemutatni. Célul tűztük ki annak vizsgálatát, hogy a zalaegerszegi technológia melléktermékeként keletkező pirolízis koksz hatékonyan alkalmazható-e szintézisgáz előállítására. Összehasonlításként ugyanazon laboratóriumi berendezésben felsőnyárádi barnaszén elgázosításával kapcsolatban is végeztünk kísérleteket.

\section{Anyagok és módszerek}

Az elgázosítási kísérletek során RDF hőbontásával előállított pirolízis kokszot és felsőnyárádi barnaszenet alkalmaztunk alapanyagként. A pirolízis koksz egy Zalaegerszegen működő félüzemi méretű kísérleti RDF pirolizálóból származik. Az alapanyagok elemi összetételét és nedvességtartalmát az 1. táblázat szemlélteti.

\begin{tabular}{|c|c|c|c|c|c|}
\hline Alapanyag & C & H & N & S & $\begin{array}{c}\text { Nedvesség- } \\
\text { tartalom }\end{array}$ \\
\hline RDF koksz & 38,0 & 1,0 & 1,0 & 0,3 & 9,5 \\
\hline $\begin{array}{c}\text { felsőnyárádi } \\
\text { barnaszén }\end{array}$ & 40,6 & 4,1 & 0,6 & 4,3 & 11,6 \\
\hline
\end{tabular}

1. táblázat. Az alapanyagok elemi összetétel és nedvességtartalom vizsgálatának eredményei $(\mathrm{m} / \mathrm{m} \%)$.

A vizsgált minták hasonló karbontartalommal rendelkeztek. Jelentős kéntartalom a felsőnyárádi barnaszén esetén figyelhető meg. Ugyanakkor a pirolízis koksz összetételét nagymértékben befolyásolja az RDF minősége, amelyből előállítják, így egy RDF kokszot feldolgozó technológiánál fontos felkészülni arra, hogy később akár jelentős mértékben változhat az alapanyag összetétele.

Az elgázosítási kísérletekhez összeállítottunk egy laboratóriumi berendezést (Hiba! A hivatkozási forrás nem található.), melyben az elgázosításhoz szükséges hőmérsékletet 2 elektromos fütésű 
csőkemence biztosította. Reaktorként egy saválló acélcsövet alkalmaztunk, melynek az első kemence által fútött csőszakaszában kerültek elhelyezésre az egyes alapanyagok.

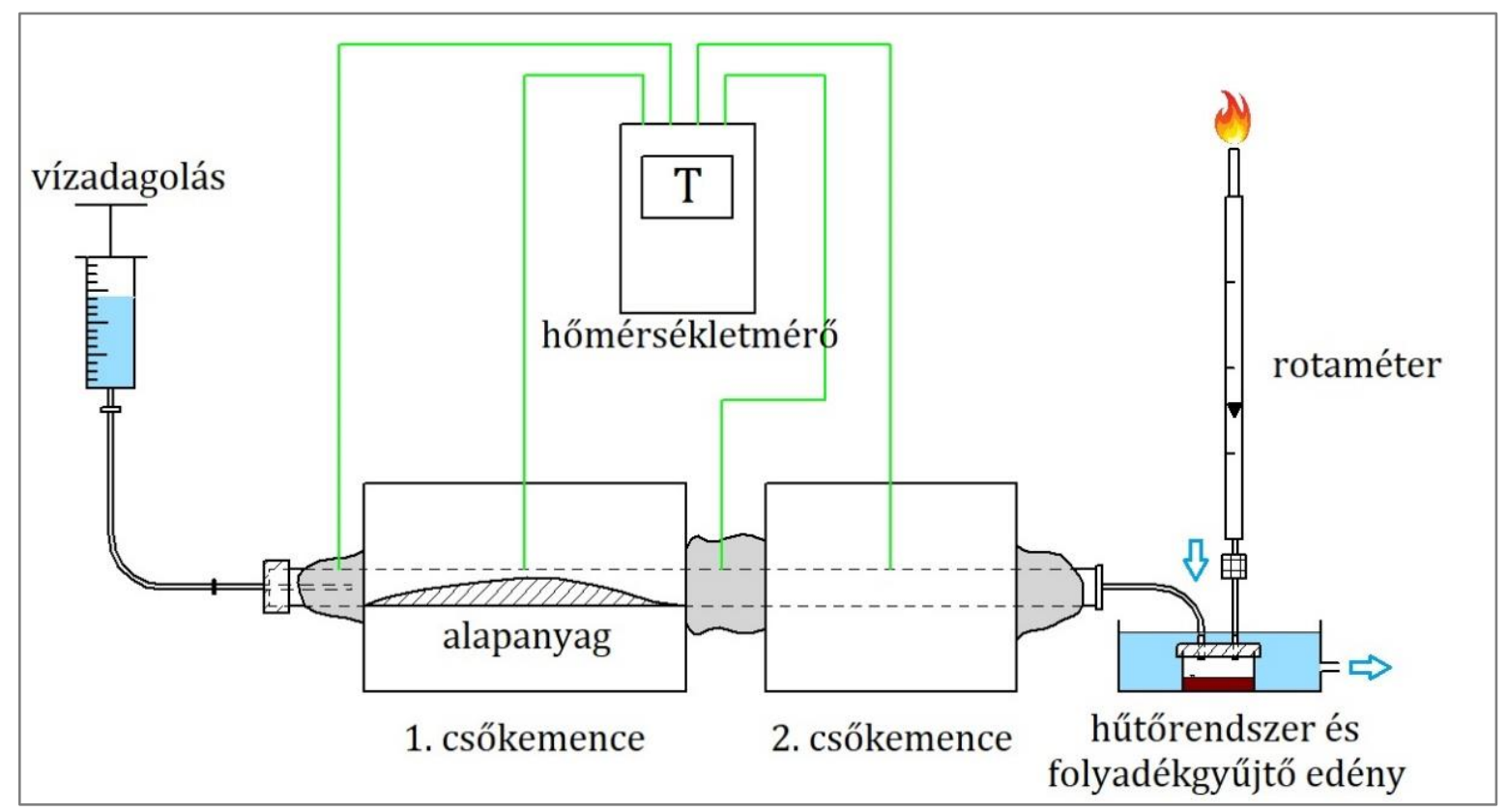

1. ábra. A laboratóriumi elgázosító rendszer sematikus ábrája.

Gázosító közegként vízgőzt alkalmaztunk, a vízadagolás $10 \mathrm{~mL} / \mathrm{h}$-val történt. A kísérleteket $900{ }^{\circ} \mathrm{C}$-on végeztük el. A két kemence fütése különböző időpontokban kezdődött el, a második kemencét akkor kapcsoltuk be, amikor az alapanyaggal töltött első kemence hőmérséklete már elérte a $700{ }^{\circ} \mathrm{C}$-ot. A gázosító közeg bevezetése egy infúzió adagoló készülék segítségével valósult meg, amikor már mindkét kemence hőmérséklete elérte a $900{ }^{\circ} \mathrm{C}$-ot. A második kemence alkalmazásával a képződő gázok tartózkodási idejét kívántuk megnövelni a rendszerben, ezáltal biztosítva a megfelelő mértékű lebomlásukhoz szükséges időt. A reaktorból kilépő gázt lehűtöttük, ezt követően térfogatáramának változását rotaméterek segítségével követtük nyomon. Bizonyos időközönként a gázból mintákat vettünk, melyek elemzését egy TCD és FID detektorral szerelt DANI Master GC típusú gázkromatográffal végeztük el. A reaktor kialakításából adódóan az elgázosítási fázis kezdetekor az alapanyagok már veszítettek illó-tartalmukból, ugyanis a felfütés során a nagy hőmérséklet hatására elkezdődött azok pirolízise.

\section{Kísérleti eredmények}

A 2. ábra a pirolízis koksz elgázosításakor képződő szintézisgáz térfogatáramának változását, valamint az egyes gázminták kromatográfiás elemzéseinek eredményét mutatja be. A vízgőz bevezetését követően a termelt gáz térfogatárama perceken belül megközelítette a $11 \mathrm{dm}^{3} / \mathrm{kg}$-ot, majd mennyisége fokozatosan csökkenni kezdett. Minden vizsgált mintánál a gáz legalább 89 V/V\%-át szén-dioxid, szénmonoxid és hidrogén alkotta. Egyes minták tartalmaztak még 0,5 V/V\% kén-hidrogént, a fennmaradó részben pedig metánt és egyéb szénhidrogéneket. A reaktor felfütése során képződő pirolízisgázok a teljes gáztermelés megközelítőleg 6,5 V/V\%-át tették ki. Az RDF kokszból pirolízis gázok $700{ }^{\circ} \mathrm{C}$-ot 
meghaladó hőmérsékleten képződtek, ugyanis a zalaegerszegi berendezésben ezen a hőmérsékleten zajlik az RDF pirolízise.

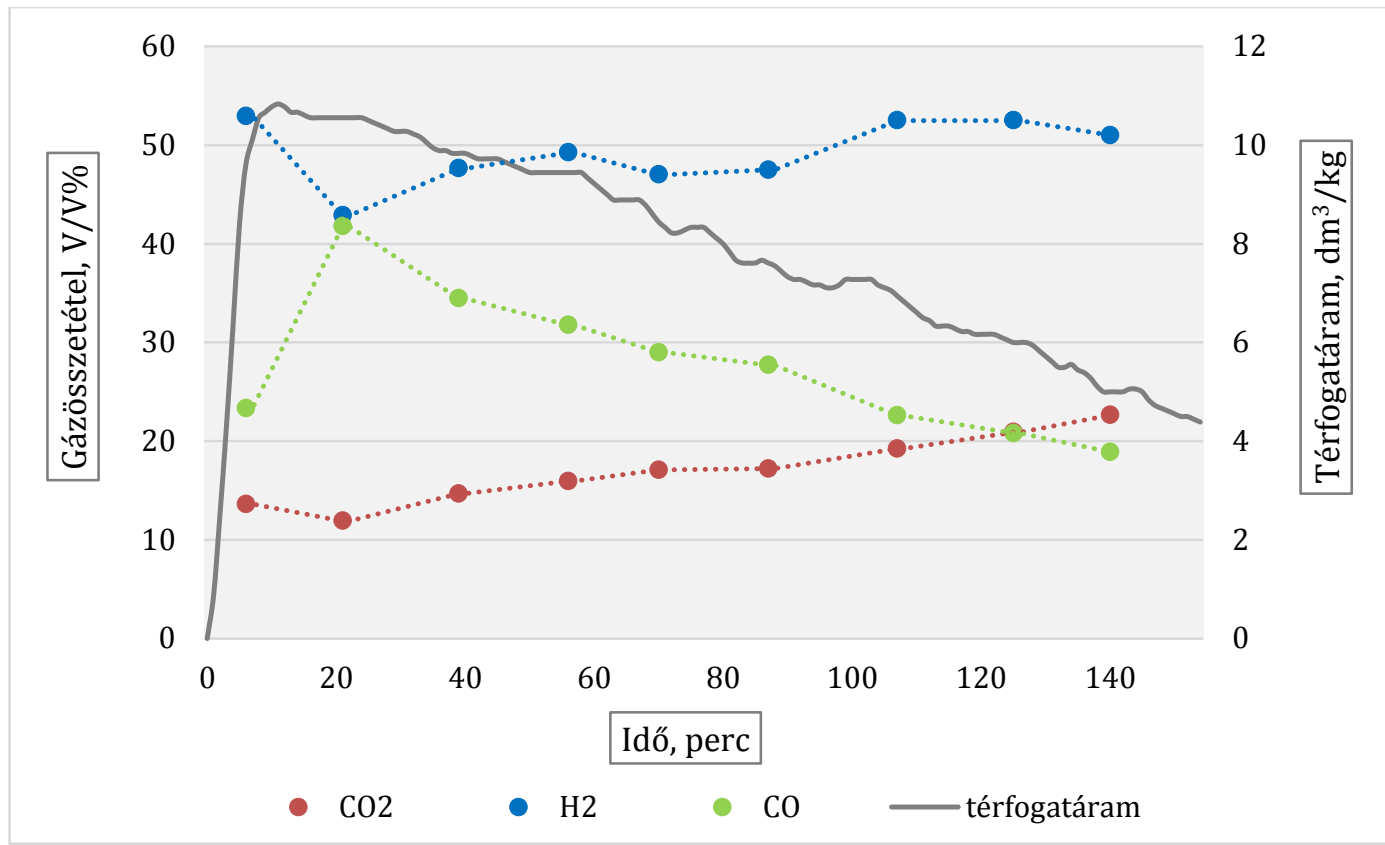

2. ábra. A pirolízis koksz elgázosítása során képződő szintézisgáz térfogatáramának változása és fô komponensei.

A felsőnyárádi barnaszén elgázosításakor (3. ábra) kevesebb szintézisgáz képződött, a maximális térfogatáram 9,3 $\mathrm{dm}^{3} / \mathrm{kg}$ volt. A gázösszetétel hasonló módon alakult, mint a pirolízis koksz elgázosításakor. Kén-hidrogént csak az első (0,3 V/V\%) és utolsó $(0,9 \mathrm{~V} / \mathrm{V} \%)$ minta esetében mutatott ki a gázkromatográf, melynek alsó mérési határértéke $0,2 \mathrm{~V} / \mathrm{V} \%$. A pirolizálási fázisban a felsőnyárádi barnaszénből a teljes termelt gáz mennyiségének mindössze 2 V/V\%-a távozott.

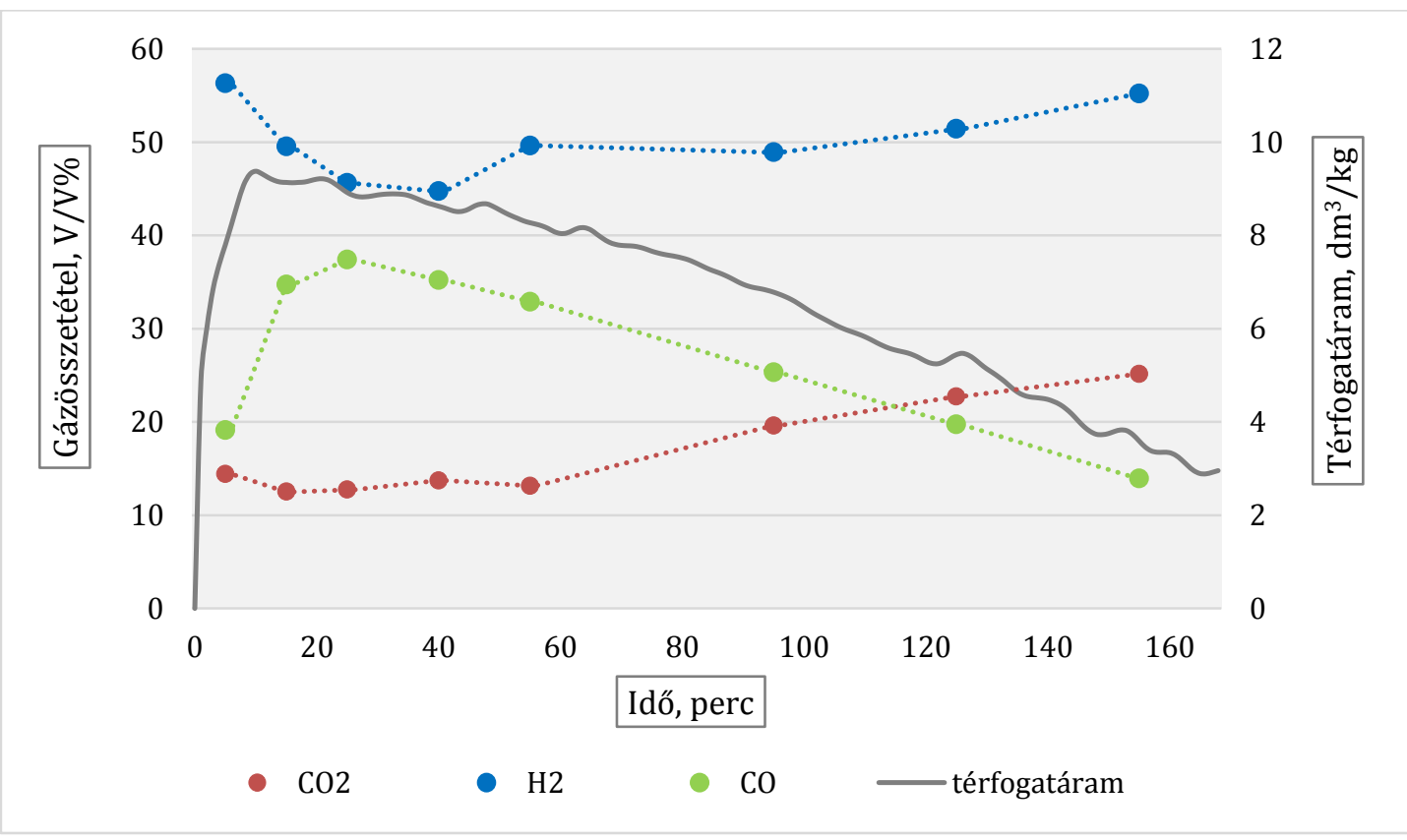

3. ábra. A felsőnyárádi barnaszén elgázosítása során képződő szintézisgáz térfogatáramának változása és fö komponensei. 
A karbontartalmú anyagok vízgőzzel történő elgázosítása során a gázképződést döntően az alábbi három reakció határozza meg [9]:

- gőzgázosítási reakció:

$$
\begin{gathered}
\mathrm{H}_{2} \mathrm{O}+\mathrm{C} \rightarrow \mathrm{H}_{2}+\mathrm{CO} \\
\mathrm{H}_{2} \mathrm{O}+\mathrm{CO} \leftrightarrow \mathrm{H}_{2}+\mathrm{CO}_{2} \\
\mathrm{CO}_{2}+\mathrm{C} \leftrightarrow 2 \mathrm{CO}
\end{gathered}
$$$$
\text { - Bouduard reakció: }
$$

A 2. és 3. ábrát összehasonlítva látható, hogy mindkét alapanyag elgázosítása során ugyanazon reakciók zajlottak le. A vízgőz bevezetését követően, amikor a képződő szintézisgáz térfogatárama már relatíve stabilizálódott eleinte a gőzgázosítási reakció dominált. A kísérlet lefolytatása alatt a hidrogén koncentráció végig magas volt, megközelítőleg átlagosan 45-50 V/V\%. A kísérlet előrehaladtával a szén-monoxid aránya csökkenni, a szén-dioxidé pedig nőni kezdett a szintézisgázban.

A Hiba! A hivatkozási forrás nem található. szemlélteti számszerűsítve a karbon mennyiségének változását az alapanyagokban, valamint az ábra jobb oldalán a reaktorcsőbe helyezett anyagok láthatók elgázosítás előtti és utáni állapotukban.

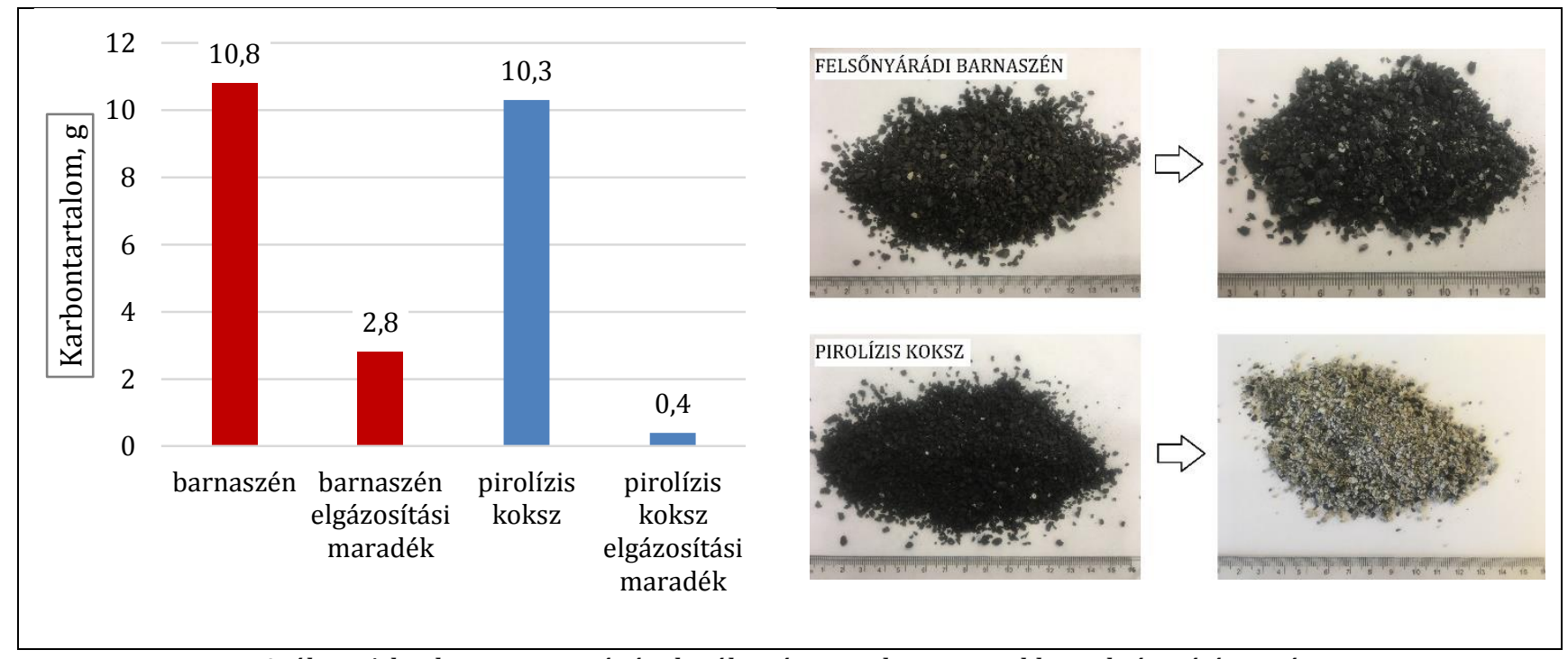

4. ábra. A karbon mennyiségének változása az alapanyagokban elgázosítás során.

Az elgázosítási maradékanyagokra vonatkozó vizsgálatok eredményei alapján a karbon nagyobb arányban alakult át a pirolízis koksz esetében. A karbontartalomban bekövetkezett nagymértékü csökkenés a pirolízis kokszról készült fotókon is látszik, a barnaszén esetében a színbeli változás kevésbé szembetűnő. Ez magyarázhatja, hogy habár a barnaszén kezdeti karbontartalma meghaladta a pirolízis kokszét, mégis az utóbbi elgázosításakor képződött nagyobb mennyiségű szintézisgáz. A két alapanyagban bekövetkező karbonkonverziók közötti különbséget az alapanyagok szerkezeti különbségei okozhatták. Az alapanyag pórusszerkezetében jelentős változások következnek be pirolízis során az illók távozásakor. A megnövekedett pórustérfogat és fajlagos felület teszi alkalmassá a pirolízis kokszot az adszorbensként történő felhasználásra is [10,11]. 


\section{Összefoglalás}

Kísérleti eredményeink alapján a zalaegerszegi RDF pirolizáló technológia melléktermékeként képződő pirolízis koksz alkalmas szintézisgáz előállítására. Figyelembe véve a felfütés során képződő pirolízis gázok mennyiségét is megállapítható, hogy az RDF koksz alacsonyabb kezdeti karbontartalma ellenére ugyanazon körülmények között több gáz előállítására alkalmas, mint a felsőnyárádi barnaszén. Ezt valószínűsíthetően a két alapanyag szerkezeti különbségei okozzák. Annak érdekében, hogy erről megbizonyosodjunk, a jövőben az alapanyagok fajlagos felületére és porozitására vonatkozó méréseket is végre kívánunk hajtani.

\section{Köszönetnyilvánítás}

Az Innovációs és Technológiai Minisztérium ÚNKP-19-3 kódszámú Új Nemzeti Kiválóság Programjának szakmai támogatásával készült.

\section{Hivatkozások}

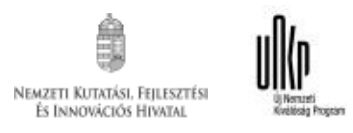

[1] H. Ritchie, and M. Roser. Fossil fuels, https://ourworldindata.org/fossil-fuels.

[2] J. Preciado-Hernandez, J. Zhang et al., An experimental study of $\mathrm{CO}_{2}$ gasification kinetics during activation of a spent tyre pyrolysis char, Chemical Engineering Research and Design, vol. 149, pp. 129-137, 2019.

[3] W. Zhua, W. Songa, and W. Lina, Catalytic gasification of char from co-pyrolysis of coal and biomass, Fuel Processing Technology, vol. 89, no. 9, pp. 890-896, 2008.

[4] D. Chen, L. Yin, H. Wang et al., Pyrolysis technologies for municipal solid waste: A review, Waste Management, vol. 37, no. 12, pp. 116-136, 2015.

[5] E. C. Efika, J. A. Onwudili, and P. T. Williams, Products from the high temperature pyrolysis of RDF at slow and rapid heating rates, Journal of Analitical and Applied Pyrolysis, vol. 112, pp. 14-22, 2015.

[6] C. Ryu, V. N. Sharifi, and J. Swithenbank, Waste pyrolysis and generation of storable char, 177-191, International Journal of Energy Research, 2007.

[7] H. W. Lee, R.-s. Park, S. H. Park et al., Cü2+ ion reduction in wastewater over RDF-derived char, Carbon Letters, 2016, pp. 49-55.

[8] H. Haykiri-Acma, S. Yaman, and S. Kucukbayrak, Gasification of biomass chars in steam-nitrogen mixture, Energy Conversion and Management, 2006, pp. 1004-1013.

[9] Q. Xu, S. Pang, and T. Levi, Reaction kinetics and producer gas compositions of steam gasification of coal and biomass blend chars, part 2: Mathematical modelling and model validation, Chemical Engineering Science, vol. 66, pp. 2232-2240, 2011.

[10] P. Fu, S. Hu, J. Xiang et al., Effect of Pyrolysis Temperature on Characteristics of Porosity in biomass chars.

[11] C. I. Contescu, S. P. Adhikari, N. C. Gallego et al., Activated Carbons Derived from High Temperature Pyrolysis of Lignocellulosic Biomass, Journal of Carbon Research, 2018. 